\title{
The Examination of Teachers' Levels of Organizational Happiness
}

\author{
Hatice Vatansever Bayraktar ${ }^{1} \&$ Sinan Girgin ${ }^{2}$ \\ ${ }^{1}$ Phd., Assoc. Prof, Primary School Education, Education Faculty, Istanbul Sabahattin Zaim University, Turkey \\ ${ }^{2}$ Phd Student, Educational Management and Supervision Department, Social Studies Institute, Okan University, \\ Istanbul, Turkey \\ Correspondence: Hatice Vatansever Bayraktar, Assoc. Prof. Dr, https://orcid.org/0000-0002-0458-3405, \\ Education Faculty, Istanbul Sabahattin Zaim University, Turkey. E-mail: hatice.bayraktar@izu.edu.tr
}

Received: April 30, 2020 Accepted: August 18, 2020 Online Published: September 11, 2020

doi:10.5539/jel.v9n5p170 URL: https://doi.org/10.5539/jel.v9n5p170

\begin{abstract}
This study aims to investigate the levels of organizational happiness of teachers working in primary, secondary, and high schools and to determine whether there is a significant difference in terms of some demographic characteristics. The screening model was employed in the study. The study population consists of teachers working in the Küçükçekmece, Bağcılar, Avcılar, and Esenyurt districts during the 2017-2018 academic year. The sample of the study comprises 297 teachers working in the Küçükçekmece, Bağcılar, Avcılar, and Esenyurt districts and selected via the convenience/incidental sampling method. In the study, the "Personal Information Form" created by the researchers and the "School Happiness Scale" developed by Bulut (2015) were used as data collection tools. The SPSS packaged software was used in the data analysis. According to the results of the data analysis, teachers' general happiness perceptions and organizational happiness perceptions were observed to be high according to the subdimensions of management processes, attitudes towards the teaching profession, communication, commitment and economic provision of the School Happiness Scale. Teachers' perceptions of organizational happiness differed significantly according to the level of education taught by teachers in the subdimensions of management processes and economic provision of the School Happiness Scale. Teachers' perceptions of organizational happiness differed significantly according to professional seniority in the management processes subdimension of the School Happiness Scale. Teachers' perceptions of organizational happiness differed significantly in the subdimensions of management processes, attitudes towards the teaching profession, commitment, and economic provision of the School Happiness Scale and according to the branch variable in the overall total. Teachers' perceptions of organizational happiness did not differ significantly according to the variables of gender, educational status, age, and seniority in the school where they worked.
\end{abstract}

Keywords: teacher, organizational happiness, level of happiness

\section{Introduction}

The concept of happiness, which has increasing importance nowadays, has maintained its significance since the beginning of history, and individuals alone and societies altogether have made efforts to achieve happiness. This concept, which is the meaning of life for everyone, has been the subject of studies and explanations in many disciplines such as psychology, medicine, and economy. Furthermore, many scientists, thinkers, and social researchers have discussed and defined happiness in different ways and with different approaches (Akduman \& Yüksekbilgili, 2015). Some thinkers explained the concept based on religious terminology, while others defined it from a hedonist and eudaemonic perspective. Farabi used happiness in the sense of "conscientious comfort" and "path to follow by acquiring virtues" (Özgen, 2005). Descartes defined happiness as follows, "Happiness is full spiritual satisfaction and inner contentment" (Türkben, 2010). According to the Turkish Language Association, happiness is defined as "pleasure, gladness, prosperity, delightfulness, well-being, bliss, felicity achieved for fully and continuously fulfilling all the longing" (TLA, 2020). Hills and Argyle (2002) described happiness as a pleasant and desired characteristic that depends on the personal attitude and instincts and results from positive feelings and satisfaction with life. Ekman and Friesen (2003) defined happiness as "a spiritual state containing feelings such as enjoying, feeling excited and relaxing and a general positivity beyond these feelings." Veenhoven (2008) expressed happiness as a person's enjoying life as a whole in the general sense. Franklin (2010) defined happiness as "a positive feeling that has a long effect on people and consists of a series of satisfied pleasures." 
According to Pryce-Jones (2011), happiness is "the mentality enabling the person to achieve his potential."

The happiness of people working in an organization may lead to other positive situations. For example, employees with more intense positive feelings in the organization can be more productive for their organization, create better outputs, and, consequently, display their potential at a higher level. Different studies have reported that employees in organizations where organizational happiness is ensured are more productive (Bryson, Forth, \& Stokes, 2015). The happiness of teachers is a crucial factor in the efficiency of education and teaching. In light of this information, it can be said that the most significant output of a school with happy and productive teachers will be healthy, productive, and happy individuals, who will form a good society (Gavin \& Mason, 2004).

Upon examining the studies conducted on the subject, the studies titled "Analyzing Levels of Happiness of Individuals with Ordinal Logistic Analysis" made by Akın and Şentürk (2012), "Effects of Leisure Time Spent on Internet to University Students' Happiness and Life Satisfaction Levels" by Göral (2013), "Analyzing the Relation of Happiness with Authenticity and Self-Compassion Among Candidate Teachers" by Duman (2014), "Perceptions of High School Teachers' Organizational Happiness: A Norm Study" by Bulut (2015), “The Relationship Between School Administrators' Happiness Level and Their Self-Efficacy Levels" by Duran (2016), "The Political Skills of Teachers as a Factor Predicting School Happiness" by Özgenel and Bozkurt (2020), "Measurement of Organizational Happiness" by Eckhaus (2018), "Hapiness at Work" by Fisher (2010), "Organizational Happiness" by Juul (2018), "Organizational Happiness Index (OHI): A Study of a Public University in Malaysia" by Omar, Ramdani, Mohd and Hussein (2018), "Workplace happiness: organizational role and the reliability of self-reporting" by Huang (2016), "Çalışma Mutluluğu: Kavram ve Kapsam" by Turan (2018), "Happiness and well-being at work" by Stoia (2015), "The Relationship Between Teacher Perceptions of Diversity Management Perspectives and Organizational Happiness" by Arslan (2018), "Analysis of Secondary School Teachers' Perceptions of Organizational Happiness" by Çetin and Polat (2019), "A Study on Lifelong Learning Tendencies and Happiness Levels of Teachers (Kocaeli Sample)" by Kabal (2019), "Relation Between Institutional Contentment of Students And Teachers In Spatial Arrangement On School" by Sancak (2019), "Investigation of The Relationship Between Emotional Intelligence Levels And Happiness of Sports Executives Due to Local Administrations and Youth Services Sports Directorate" by Serter (2019), "The Relationship Between Learning School and School Happiness" by Uğur (2019) were encountered. However, there is no study that studies the happiness levels of teachers working in primary, secondary and high schools in Istanbul. In this respect, it is thought that the study will contribute to the field. In this context, the main objective of this study was indicated as "to examine the levels of teachers' perceptions of organizational happiness and the differentiation status of their happiness perceptions according to gender, educational status, age, professional seniority, seniority in the school where they work, branch, and the level of education taught." The sub-goals determined within the scope of this main objective are as follows:

1) What is the level of teachers' organizational happiness?

2) Does the level of teachers' organizational happiness differ according to gender, educational status, age, professional seniority, seniority in the school where they work, branch, and the level of education taught?

\section{Method}

\subsection{Research Design}

The screening model was employed in the study. Screening studies usually make a description of the subject investigated (Büyüköztürk, Çakmak, Akgün, Karadeniz, \& Demirel, 2012).

\subsection{Population and Sample}

The study population consists of teachers working in the Küçükçekmece, Bağcılar, Avcılar, and Esenyurt districts. The sample of the study comprises teachers working in the Küçükçekmece, Bağcılar, Avcılar, and Esenyurt districts and selected via the convenience/incidental sampling method. While determining participants, the convenience/incidental sampling method, one of the non-random sampling methods, was used. The convenience/incidental sampling method represents the selection of a sample from accessible units, on which implementation will be easy, due to time and labor force limitations (Büyüköztürk, K1lıç-Çakmak, Akgün, Karadeniz, \& Demirel, 2012). Of 297 individuals, 201 (67.7\%) were women, and 96 $(32.3 \%)$ were men according to the frequency and percentage distributions of the demographic characteristics of the sample. Of the participants, $180(60.6 \%)$ were at the age of $24-34,101(34.0 \%)$ at the age of 35-45, and $16(5.4 \%)$ at the age of 46 and above. Of the participants, 257 (86.5\%) had a bachelor's 
degree, and $40(13.5 \%)$ were postgraduates. It was found that $88(29.6 \%)$ of the participants had professional seniority of $0-5$ years, $105(35.4 \%)$ of $6-10$ years, $57(19.2 \%)$ of $11-15$ years, and $47(15.8 \%)$ had professional seniority of 16 years and above. It was determined that $203(68.4 \%)$ of the participants had seniority in the school of $0-5$ years, $57(19.2 \%)$ of $6-10$ years, $23(7.7 \%)$ of $11-15$ years, and $14(4.7 \%)$ of 16 years and above. Of the participants, $83(27.9 \%)$ were teachers in verbal branches, $62(20.9 \%)$ were mathematics/science teachers, $63(21.2 \%)$ were teachers in other branches, and $89(30.0 \%)$ were primary school teachers. Of the participants, $141(47.5 \%)$ worked in primary schools, $57(19.2 \%)$ in secondary schools, and 99 (33.3\%) worked in high schools.

\subsection{Data Collection Tools}

In the study, the Personal Information Form and the Organizational Happiness Scale were used as data collection tools.

Personal Information Form: In the personal information form, there are seven questions about gender, age, educational status, professional seniority, seniority in the school, branch, and the level of education taught.

Organizational Happiness Scale: The happiness levels of teachers concerning their schools were measured by the "Organizational Happiness Scale" developed and studied for validity and reliability by Bulut (2015). The scale consists of the subdimensions of "Management Processes (1-2-3-4-5-6-7-8-9-10-11-12-13-14-15-16-17), Attitudes Towards the Teaching Profession (18-19-20-21-22-23-24-25-26), Communication (27-28-29-30), Commitment (31-32-33-34), and Economic Provision (35-36-37-38)." The Organizational Happiness Scale was prepared in the form of "(1) I Strongly Disagree - (5) I Strongly Agree."

\subsection{Data Analysis}

The SPSS packaged software was used in the data analysis and the significance level was taken as 0.05 among the variables. In data analysis, arithmetic mean and standard deviation were calculated, the t-test analysis of the levels of teachers' organizational happiness was performed according to the variables of gender and educational status, and the ANOVA analysis was conducted according to the variables of age, professional seniority, seniority in the school, branch and the level of education taught.

\section{Results}

In this section, results and interpretation of the study data are presented.

\subsection{Levels of Teachers' Organizational Happiness}

Descriptive statistics related to the levels of teachers' organizational happiness are presented in Table 1.

Table 1. Descriptive statistical analysis results of the levels of teachers' organizational happiness

\begin{tabular}{lll}
\hline Organizational Happiness Scale & $\overline{\mathbf{X}}$ & sd \\
\hline Management Processes & 3.80 & 0.59 \\
Teaching Profession & 4.12 & 0.62 \\
Communication & 4.12 & 1.00 \\
Commitment & 3.82 & 0.70 \\
Economic Provision & 3.47 & 0.80 \\
General Organizational Happiness & 3.87 & 0.52 \\
\hline
\end{tabular}

When Table 1 is examined, it is observed that the levels of teachers' organizational happiness take the arithmetic mean value of $\bar{x}=3.80$ in the management processes subdimension, $\bar{x}=4.12$ in the subdimension of attitudes towards the teaching profession and communication, $\bar{x}=3.82$ in the commitment subdimension, $\bar{x}=3.47$ in the economic provision subdimension, and $\bar{x}=3.87$ in the subdimension of the total level of organizational happiness. Teachers' general happiness perceptions and organizational happiness perceptions were observed to be high according to the subdimensions of management processes, attitudes towards the teaching profession, communication, commitment, and economic provision of the Organizational Happiness Scale.

\subsection{Examination of the Levels of Teachers' Organizational Happiness According to the Gender Variable}

The differentiation status between the organizational happiness levels of teachers according to their gender was evaluated by the t-test, and the results are presented in Table 2 . 
Table 2. The t-test analysis of the levels of teachers' organizational happiness according to the gender variable

\begin{tabular}{|c|c|c|c|c|c|c|c|}
\hline Organizational Happiness Scale & Gender & $\mathbf{N}$ & $\overline{\mathrm{x}}$ & sd & df & $\mathbf{t}$ & $\mathbf{p}$ \\
\hline \multirow[t]{2}{*}{ Management Processes } & Female & 201 & 3.79 & .54 & 295 & -.482 & .630 \\
\hline & Male & 96 & 3.83 & .69 & & & \\
\hline \multirow[t]{2}{*}{ Teaching Profession } & Female & 201 & 4.17 & .56 & 295 & 1.935 & .054 \\
\hline & Male & 96 & 4.02 & .71 & & & \\
\hline \multirow[t]{2}{*}{ Communication } & Female & 200 & 4.16 & 1.10 & 295 & 1.056 & .292 \\
\hline & Male & 96 & 4.03 & .77 & & & \\
\hline \multirow[t]{2}{*}{ Commitment } & Female & 200 & 3.84 & .66 & 295 & .930 & .353 \\
\hline & Male & 96 & 3.76 & .78 & & & \\
\hline \multirow[t]{2}{*}{ Economic Provision } & Female & 200 & 3.48 & .77 & 295 & .217 & .829 \\
\hline & Male & 96 & 3.45 & .86 & & & \\
\hline \multirow[t]{2}{*}{ General Organizational Happiness } & Female & 201 & 3.89 & .49 & 295 & 1.113 & .267 \\
\hline & Male & 96 & 3.82 & .59 & & & \\
\hline
\end{tabular}

When Table 2 was examined, no significant difference could be detected between the levels of organizational happiness regarding the subdimensions of management processes $(t(297)=-.482, p>0.05)$, attitudes towards the teaching profession $(\mathrm{t}(297)=1.935, \mathrm{p}>0.05)$, communication $(\mathrm{t}(297)=1.056, \mathrm{p}>$ $0.05)$, commitment $(\mathrm{t}(297)=.930, \mathrm{p}>0.05)$, and economic provision $(\mathrm{t}(297)=.217, \mathrm{p}>0.05)$, and the total level of organizational happiness $(\mathrm{t}(297)=1.113, \mathrm{p}>0.05)$ according to teachers' gender.

\subsection{Examination of the Levels of Teachers' Organizational Happiness According to the Educational Status Variable}

The differentiation status between the organizational happiness levels of teachers according to their educational status was evaluated by the t-test, and the results are presented in Table 3 .

Table 3. The t-test analysis of the levels of teachers' organizational happiness according to the educational status variable

\begin{tabular}{llllllll}
\hline Organizational Happiness Scale & Educational Status & $\mathbf{N}$ & $\overline{\mathbf{X}}$ & $\mathbf{s d}$ & $\mathbf{d f}$ & $\mathbf{t}$ & $\mathbf{p}$ \\
\hline Management Processes & Undergraduate & 257 & 3.79 & .56 & 295 & -.815 & .416 \\
& Postgraduate & 40 & 3.88 & .79 & & & \\
Teaching Profession & Undergraduate & 257 & 4.11 & .60 & 295 & -.472 & .638 \\
& Postgraduate & 40 & 4.16 & .71 & & & \\
Communication & Undergraduate & 256 & 4.13 & 1.03 & 295 & .258 & .797 \\
& Postgraduate & 40 & 4.08 & .84 & & & \\
Commitment & Undergraduate & 256 & 3.79 & .69 & 295 & -1.360 & .175 \\
Economic Provision & Postgraduate & 40 & 3.96 & .77 & & & \\
& Undergraduate & 256 & 3.47 & .78 & 295 & .036 & \\
General Organizational Happiness & Postgraduate & 40 & 3.46 & .92 & & & \\
& Undergraduate & 257 & 3.86 & .50 & 295 & -.524 & .601 \\
& Postgraduate & 40 & 3.91 & .64 & & & \\
\hline
\end{tabular}

According to Table 3, there was no significant difference between the levels of organizational happiness regarding the subdimensions of management processes $(\mathrm{t}(297)=-.815, \mathrm{p}>0.05)$, attitudes towards the teaching profession $(\mathrm{t}(297)=-.472, \mathrm{p}>0.05)$, communication $(\mathrm{t}(297)=.258, \mathrm{p}>0.05)$, commitment $(\mathrm{t}(297)$ $=-1.360, \mathrm{p}>0.05)$, and economic provision $(\mathrm{t}(297)=.036, \mathrm{p}>0.05)$, and the total level of organizational happiness $(\mathrm{t}(297)=-.524, \mathrm{p}>0.05)$ according to teachers' educational status.

\subsection{Examination of the Levels of Teachers' Organizational Happiness According to the Age Variable}

The differentiation status between the organizational happiness levels of teachers according to their age was analyzed by the one-way analysis of variance, and the results are presented in Table 4 . 
Table 4. ANOVA analysis of the levels of teachers' organizational happiness according to the age variable

\begin{tabular}{|c|c|c|c|c|c|c|}
\hline Organizational Happiness Scale & & Sum of Squares & df & Mean of Squares & $\mathbf{F}$ & $\mathbf{p}$ \\
\hline \multirow[t]{3}{*}{ Management Processes } & Intergroup & 1.064 & 2 & .532 & 1.489 & .227 \\
\hline & Intragroup & 105.092 & 294 & .357 & & \\
\hline & Total & 106.156 & 296 & & & \\
\hline \multirow[t]{3}{*}{ Teaching Profession } & Intergroup & .131 & 2 & .066 & .169 & .845 \\
\hline & Intragroup & 113.973 & 294 & .388 & & \\
\hline & Total & 114.104 & 296 & & & \\
\hline \multirow[t]{3}{*}{ Communication } & Intergroup & .201 & 2 & .100 & .098 & .907 \\
\hline & Intragroup & 300.049 & 293 & 1.024 & & \\
\hline & Total & 300.250 & 295 & & & \\
\hline \multirow[t]{3}{*}{ Commitment } & Intergroup & .084 & 2 & .042 & .084 & .920 \\
\hline & Intragroup & 148.051 & 293 & .505 & & \\
\hline & Total & 148.135 & 295 & & & \\
\hline \multirow[t]{3}{*}{ Economic Provision } & Intergroup & .736 & 2 & .368 & .568 & .567 \\
\hline & Intragroup & 189.923 & 293 & .648 & & \\
\hline & Total & 190.659 & 295 & & & \\
\hline \multirow[t]{3}{*}{ General Organizational Happiness } & Intergroup & .087 & 2 & .044 & .156 & .855 \\
\hline & Intragroup & 82.092 & 294 & .279 & & \\
\hline & Total & 82.180 & 296 & & & \\
\hline
\end{tabular}

When Table 4 was examined, no significant difference could be found between the levels of organizational happiness regarding the subdimensions of management processes $(\mathrm{F}(2-294)=1.489, \mathrm{p}>0.05)$, attitudes towards the teaching profession $(\mathrm{F}(2-294)=.169, \mathrm{p}>0.05)$, communication $(\mathrm{F}(2-294)=.098, \mathrm{p}>0.05)$, commitment $(\mathrm{F}(2-294)=.084, \mathrm{p}>0.05)$, and economic provision $(\mathrm{F}(2-294)=.568, \mathrm{p}>0.05)$, and the total level of organizational happiness $(\mathrm{F}(2-294)=.156, \mathrm{p}>0.05)$ according to teachers' age.

3.5 Examination of the Levels of Teachers' Organizational Happiness According to the Professional Seniority Variable

The differentiation status between the organizational happiness levels of teachers according to their professional seniority was evaluated by the one-way analysis of variance, and the results are presented in Table 5.

Table 5. ANOVA analysis of the levels of teachers' organizational happiness according to the professional seniority variable

\begin{tabular}{|c|c|c|c|c|c|c|c|}
\hline Organizational Happiness Scale & & Sum of Squares & df & Mean of Squares & $\mathbf{F}$ & $\mathbf{p}$ & Significant Difference \\
\hline \multirow[t]{3}{*}{ Management Processes } & Intergroup & 3.188 & 3 & 1.063 & 3.024 & .030 & $\mathbf{0 - 5} / 6-10$ \\
\hline & Intragroup & 102.968 & 293 & .351 & & & $\mathbf{0 - 5} / 11-15$ \\
\hline & Total & 106.156 & 296 & & & & $\mathbf{1 6}$ and above / 11-15 \\
\hline \multirow[t]{3}{*}{ Teaching Profession } & Intergroup & 2.125 & 3 & .708 & 1.853 & .138 & \\
\hline & Intragroup & 111.979 & 293 & .382 & & & _- \\
\hline & Total & 114.104 & 296 & & & & \\
\hline \multirow[t]{3}{*}{ Communication } & Intergroup & 2.123 & 3 & .708 & .693 & .557 & \\
\hline & Intragroup & 298.127 & 292 & 1.021 & & & _ \\
\hline & Total & 300.250 & 295 & & & & \\
\hline \multirow[t]{3}{*}{ Commitment } & Intergroup & 1.043 & 3 & .348 & .690 & .559 & \\
\hline & Intragroup & 147.092 & 292 & .504 & & & - \\
\hline & Total & 148.135 & 295 & & & & \\
\hline \multirow{3}{*}{ Economic Provision } & Intergroup & 1.783 & 3 & .594 & .919 & .432 & \\
\hline & Intragroup & 188.876 & 292 & .647 & & & - \\
\hline & Total & 190.659 & 295 & & & & \\
\hline \multirow[t]{3}{*}{ General Organizational Happiness } & Intergroup & 1.244 & 3 & .415 & 1.501 & .214 & \\
\hline & Intragroup & 80.936 & 293 & .276 & & & - \\
\hline & Total & 82.180 & 296 & & & & \\
\hline
\end{tabular}

When Table 5 was examined, no significant difference could be found between the levels of organizational happiness regarding the subdimensions of attitudes towards the teaching profession $(F(3-293)=1.853, p>$ 
0.05), communication $(\mathrm{F}(3-293)=.693, \mathrm{p}>0.05)$, commitment $(\mathrm{F}(3-293)=.690, \mathrm{p}>0.05)$, and economic provision $(F(3-293)=.919, p>0.05)$, and the total level of organizational happiness $(F(3-293)=1.501, p>$ 0.05 ) according to teachers' professional seniority. However, a significant difference was found between the subscale scores of the management processes subdimension $(\mathrm{F}(3-293)=3.024, \mathrm{p}<0.05)$ according to the professional seniority of teachers. This difference was indicated in the significant difference column of the table. When the subscale scores of the management processes subdimension were examined according to the professional seniority variable of teachers, a significant difference was observed in favor of those with professional seniority of $0-5$ years between teachers with professional seniority of $0-5$ years and 6-10 years, in favor of those with professional seniority of $0-5$ years between teachers with professional seniority of $0-5$ years and 11-15 years, and in favor of those with professional seniority of 16 years and above between teachers with professional seniority of 16 years and above and 11-15 years.

\subsection{Examination of the Levels of Teachers' Organizational Happiness According to the Seniority in the School} Variable

The differentiation status between the organizational happiness levels of teachers according to the seniority in the school variable was evaluated by the one-way analysis of variance, and the results are presented in Table 6 .

Table 6. ANOVA analysis of the levels of teachers' organizational happiness according to the seniority in the school variable

\begin{tabular}{|c|c|c|c|c|c|c|}
\hline Organizational Happiness Scale & & Sum of Squares & df & Mean of Squares & $\mathbf{F}$ & $\mathbf{p}$ \\
\hline \multirow[t]{3}{*}{ Management Processes } & Intergroup & 1.731 & 3 & .577 & 1.619 & .185 \\
\hline & Intragroup & 104.425 & 293 & .356 & & \\
\hline & Total & 106.156 & 296 & & & \\
\hline \multirow[t]{3}{*}{ Teaching Profession } & Intergroup & 1.483 & 3 & .494 & 1.286 & .279 \\
\hline & Intragroup & 112.622 & 293 & .384 & & \\
\hline & Total & 114.104 & 296 & & & \\
\hline \multirow[t]{3}{*}{ Communication } & Intergroup & 4.482 & 3 & 1.494 & 1.475 & .221 \\
\hline & Intragroup & 295.767 & 292 & 1.013 & & \\
\hline & Total & 300.250 & 295 & & & \\
\hline \multirow[t]{3}{*}{ Commitment } & Intergroup & 3.655 & 3 & 1.218 & 2.462 & .063 \\
\hline & Intragroup & 144.480 & 292 & .495 & & \\
\hline & Total & 148.135 & 295 & & & \\
\hline \multirow[t]{3}{*}{ Economic Provision } & Intergroup & 3.332 & 3 & 1.111 & 1.731 & .161 \\
\hline & Intragroup & 187.327 & 292 & .642 & & \\
\hline & Total & 190.659 & 295 & & & \\
\hline \multirow[t]{3}{*}{ General Organizational Happiness } & Intergroup & 1.381 & 3 & .460 & 1.669 & .174 \\
\hline & Intragroup & 80.799 & 293 & .276 & & \\
\hline & Total & 82.180 & 296 & & & \\
\hline
\end{tabular}

When Table 6 was examined, no significant difference could be detected between the levels of organizational happiness regarding the subdimensions of management processes $(\mathrm{F}(3-293)=1.619, \mathrm{p}>$ $0.05)$, attitudes towards the teaching profession $(\mathrm{F}(3-293)=1.286, \mathrm{p}>0.05)$, communication $(\mathrm{F}(3-293)=1.475, \mathrm{p}>0.05)$, commitment $(\mathrm{F}(3-293)=2.462, \mathrm{p}>0.05)$, and economic provision $(\mathrm{F}(3-293)=$ $1.731, \mathrm{p}>0.05)$, and the total level of organizational happiness $(\mathrm{F}(3-293)=1.669, \mathrm{p}>0.05)$ according to teachers' seniority in the school.

\subsection{Examination of the Levels of Teachers' Organizational Happiness According to the Branch Variable}

The differentiation status between the organizational happiness levels of teachers according to the branch variable was evaluated by the one-way analysis of variance, and the results are presented in Table 7. 
Table 7. ANOVA analysis of the levels of teachers' organizational happiness according to the branch variable

\begin{tabular}{|c|c|c|c|c|c|c|c|}
\hline Organizational Happiness Scale & & Sum of Squares & df & Mean of Squares & $\mathbf{F}$ & p & Significant Difference \\
\hline \multirow[t]{3}{*}{ Management Processes } & Intergroup & 7.615 & 3 & 2.538 & 7.547 & .000 & Verbal - Mathematics-Science \\
\hline & Intragroup & 98.541 & 293 & .336 & & & Verbal - Other Verbal-Primary \\
\hline & Total & 106.156 & 296 & & & & \\
\hline \multirow[t]{3}{*}{ Teaching Profession } & Intergroup & 3.370 & 3 & 1.123 & 2.972 & .032 & Verbal - Mathematics-Science \\
\hline & Intragroup & 110.734 & 293 & .378 & & & Verbal - Other \\
\hline & Total & 114.104 & 296 & & & & \\
\hline \multirow[t]{3}{*}{ Communication } & Intergroup & 4.456 & 3 & 1.485 & 1.466 & .224 & - \\
\hline & Intragroup & 295.794 & 293 & 1.013 & & & \\
\hline & Total & 300.250 & 295 & & & & \\
\hline \multirow[t]{3}{*}{ Commitment } & Intergroup & 6.336 & 3 & 2.112 & 4.349 & .005 & Verbal - Mathematics-Science \\
\hline & Intragroup & 141.799 & 293 & .486 & & & Verbal - Other Verbal-Primary \\
\hline & Total & 148.135 & 295 & & & & \\
\hline \multirow[t]{3}{*}{ Economic Provision } & Intergroup & 13.916 & 3 & 4.639 & 7.664 & .000 & Primary- Verbal \\
\hline & Intragroup & 176.742 & 293 & .605 & & & Primary - Mathematics-Science \\
\hline & Total & 190.659 & 295 & & & & Other - Mathematics-Science \\
\hline \multirow[t]{3}{*}{ General Organizational Happiness } & Intergroup & 3.596 & 3 & 1.199 & 4.469 & .004 & Verbal - Mathematics-Science \\
\hline & Intragroup & 78.584 & 293 & .268 & & & Verbal - Other \\
\hline & Total & 82.180 & 296 & & & & Primary-Mathematics-Science \\
\hline
\end{tabular}

When Table 7 was examined, no difference was found in the communication dimension $(F(3-293)=1.466$, $p>0.05$ ) according to the branch variable of teachers. However, a significant difference was detected between the level of organizational happiness regarding the subdimensions of management processes $(\mathrm{F}(3-293)=7.547, \mathrm{p}<0.05)$, attitudes towards the teaching profession $(\mathrm{F}(3-293)=2.972, \mathrm{p}<0.05)$, commitment $(\mathrm{F}(3-293)=4.349, \mathrm{p}<0.05)$, and economic provision $(\mathrm{F}(3-293)=7.664, \mathrm{p}<0.05)$, and the total level of organizational happiness $(\mathrm{F}(3-293)=4.469, \mathrm{p}<0.05)$.

There was a significant difference among teachers in verbal branches, mathematics-science teachers, teachers in other branches, and primary school teachers when the subdimensions of "management processes" and "commitment" were examined according to the branches of teachers. This difference was in favor of teachers in verbal branches.

There was a significant difference among teachers in verbal branches, mathematics-science teachers, and teachers in other branches when the subdimension of "attitudes towards the teaching profession" was examined according to the branches of teachers. This difference was in favor of teachers in verbal branches.

There was a significant difference among primary school teachers, teachers in verbal branches, and mathematics-science teachers when the subdimension of "economic provision" was examined according to the branches of teachers. This difference was in favor of primary school teachers. A significant difference was found between teachers in other branches and mathematics-science teachers. This difference was in favor of teachers in other branches.

A significant difference was found among teachers in verbal branches, mathematics-science teachers, and teachers in other branches when the total level of organizational happiness was examined according to the branches of teachers. This difference was in favor of teachers in verbal branches. A significant difference was found between primary school teachers and mathematics-science teachers. This difference was in favor of primary school teachers.

\subsection{Examination of the Levels of Teachers' Organizational Happiness According to the Level of Education Taught Variable}

The differentiation status between the organizational happiness levels of teachers according to the variable of the level of education taught was evaluated by the one-way analysis of variance, and the results are presented in Table 8 . 
Table 8. ANOVA analysis of the levels of teachers' organizational happiness according to the level of education taught variable

\begin{tabular}{|c|c|c|c|c|c|c|c|}
\hline \multicolumn{2}{|c|}{ Organizational Happiness Scale } & \multirow{2}{*}{$\begin{array}{l}\text { Sum of Squares } \\
4.458\end{array}$} & \multirow{2}{*}{$\begin{array}{l}\text { df } \\
2\end{array}$} & \multirow{2}{*}{$\begin{array}{l}\text { Mean of Squares } \\
2.229\end{array}$} & \multirow{2}{*}{$\begin{array}{l}\text { F } \\
6.444\end{array}$} & \multirow{2}{*}{$\begin{array}{l}\mathbf{p} \\
.002\end{array}$} & \multirow{2}{*}{$\begin{array}{l}\text { Significant Difference } \\
\text { Secondary School- Primary }\end{array}$} \\
\hline Management Processes & Intergroup & & & & & & \\
\hline & Intragroup & 101.698 & 294 & .346 & & & School; High School- Primary \\
\hline & Total & 106.156 & 296 & & & & School \\
\hline \multirow[t]{3}{*}{ Teaching Profession } & Intergroup & 1.010 & 2 & .505 & 1.313 & .271 & _ \\
\hline & Intragroup & 113.094 & 294 & .385 & & & \\
\hline & Total & 114.104 & 296 & & & & \\
\hline \multirow[t]{3}{*}{ Communication } & Intergroup & .042 & 2 & .021 & .020 & .980 & _ \\
\hline & Intragroup & 300.208 & 293 & 1.025 & & & \\
\hline & Total & 300.250 & 295 & & & & \\
\hline \multirow[t]{3}{*}{ Commitment } & Intergroup & 2.195 & 2 & 1.097 & 2.203 & .112 & _- \\
\hline & Intragroup & 145.941 & 293 & .498 & & & \\
\hline & Total & 148.135 & 295 & & & & \\
\hline \multirow[t]{3}{*}{ Economic Provision } & Intergroup & 10.367 & 2 & 5.184 & 8.424 & .000 & Primary School-Secondary \\
\hline & Intragroup & 180.292 & 293 & .615 & & & School; \\
\hline & Total & 190.659 & 295 & & & & Primary School High school \\
\hline General Organizational & Intergroup & .099 & 2 & .049 & .177 & .838 & _- \\
\hline \multirow[t]{2}{*}{ Happiness } & Intragroup & 82.081 & 294 & .279 & & & \\
\hline & Total & 82.180 & 296 & & & & \\
\hline
\end{tabular}

When Table 8 was examined, no significant difference was found between the levels of organizational happiness regarding the subdimensions of attitudes towards the teaching profession $(\mathrm{F}(2-294)=1.313, \mathrm{p}>$ $0.05)$, communication $(\mathrm{F}(2-293)=.980, \mathrm{p}>0.05)$, commitment $(\mathrm{F}(2-293)=.112, \mathrm{p}>0.05)$, and the total level of organizational happiness $(\mathrm{F}(2-294)=.838, \mathrm{p}>0.05)$ according to the level of education taught by teachers. However, there was a significant difference in teachers' perceptions of organizational happiness in the subdimensions of management processes $(\mathrm{F}(2-293)=6.444, \mathrm{p}<0.05)$ and economic provision $(\mathrm{F}(2-294)$ $=8.424, \mathrm{p}<0.05)$ of the School Happiness Scale according to the level of education taught. In the economic provision subdimension, this significant difference was in favor of primary school teachers working in primary schools between teachers working in primary schools and teachers working in secondary schools, and in favor of primary school teachers working in primary schools between teachers working in primary schools and teachers working in high schools. In the management processes subdimension, this significant difference was in favor of branch teachers working in secondary schools between teachers working in primary schools and teachers working in secondary schools, and in favor of branch teachers working in high schools between teachers working in primary schools and teachers working in high schools.

\section{Conclusion, Discussion, and Recommendations}

According to the results of the data analysis, teachers' general happiness perceptions and organizational happiness perceptions were observed to be high according to the subdimensions of management processes, attitudes towards the teaching profession, communication, commitment and economic provision of the School Happiness Scale. Teachers' perceptions of organizational happiness differed significantly according to the level of education taught by teachers in the subdimensions of management processes and economic provision of the School Happiness Scale. In the economic provision subdimension, this significant difference was in favor of primary school teachers working in primary schools between teachers working in primary schools and teachers working in secondary schools, and in favor of primary school teachers working in primary schools between teachers working in primary schools and teachers working in high schools. In the management processes subdimension, this significant difference was in favor of branch teachers working in secondary schools between teachers working in primary schools and teachers working in secondary schools, and in favor of branch teachers working in high schools between teachers working in primary schools and teachers working in high schools. Teachers' perceptions of organizational happiness differed significantly according to professional seniority in the management processes subdimension of the School Happiness Scale. Teachers' perceptions of organizational happiness differed significantly in the subdimensions of management processes, attitudes towards the teaching profession, commitment, and economic provision of the School Happiness Scale and according to the branch variable in the overall total. Teachers' perceptions of organizational happiness did not differ significantly according to the variables of gender, educational status, age, and seniority in the school where they worked. 
Teachers' general happiness perceptions and organizational happiness perceptions were observed to be "high" according to the subdimensions of "management processes, attitudes towards the teaching profession, communication, commitment and economic provision" of the School Happiness Scale. When the subdimensions were ordered in terms of the high level, attitudes towards the teaching profession and communication ranked first, commitment ranked second, management processes ranked third, and economic provision ranked fourth. In their studies, Arslan (2018), Akın and Şentürk (2012), Bulut (2015), Çetin (2019), Çetin and Polat (2019), Demircan (2019), Duman (2014), Duran (2016), Göral (2013), Kabal (2019), Sancak (2019), Serter (2019), Öztürk (2015), Uğur (2019), and Yllmaz (2019) also reported that the happiness of participants was at a high level. Birdoğan-Kuvvet (2019) and Düzgün (2016), on the other hand, revealed in their studies that the happiness of participants was at a medium level. No studies revealing low levels of happiness in teachers were encountered in the literature. As a result, it can be stated that teachers' perceptions of organizational happiness are high, they feel happy in schools, they are pleased with their conditions, and they are glad to have become teachers.

There was no significant difference in teachers' perceptions of organizational happiness according to the gender variable. In their studies, Bekil (2019), Birdoğan-Kuvvet (2019), Bulut (2015), Çetin and Polat (2019), Demir (2017), Demir and Murat (2017), Demirel (2018), Duman (2014), Duran (2016), Korkut (2019), Öztaş (2018), Saygın (2008), Sevindik (2015), Şahin (2015), Şengül and Demirel (2016), and Yazıc1 (2015) reported no difference between individuals' levels of happiness in terms of the gender variable. According to the gender of teachers, their levels of organizational happiness may differ since schools offer the same conditions to both female and male teachers and they work under similar conditions and similar difficulties. Another reason for the absence of a significant difference between gender and happiness may be the relationship of happiness with inner processes and personality traits rather than demographic characteristics. Unlike this study, Akın and Şentürk (2012), Akyol (2016), Düzgün (2016), Şentürk (2011) and Yıldız-Akyol (2016) found men's levels of happiness to be higher than those of women, whereas Atay (2012), Çirkin and Göksel (2016), Çolak (2018), Erdoğan (2017), Gülcan (2014), Kangal (2013), and Şaşmaz (2016) found women's levels of happiness to be higher compared to men. These differences may result from the population, sample, and the structure of the data collection tools used.

No significant difference was found in teachers' perceptions of organizational happiness according to the educational status variable. In their studies, Düzgün (2016), Kurnaz (2015), Öğüt (2018), Öztaş (2018), Selim (2008), Sönmez (2016), Tingaz (2013) and Y1lmaz (2019) stated that there was no difference between individuals' levels of happiness in terms of the educational status factor. Within the scope of the study, it could have been thought that teachers' awareness, experiences, and their contribution to life would increase. Therefore, they would have more reasons to become happy as their educational levels increased. This may have resulted from the facts that the study was conducted on teachers, the educational levels of teachers would be at least a bachelor's degree, and the options of educational status were limited only to two options, undergraduate and graduate, as the demographic variable. Among the studies conducted, some studies are not parallel with these results. In his study, Kangal (2013) revealed that university or college graduates were happier than primary school graduates, primary education and high school graduates, and people who could not graduate from any school. According to the study carried out by Sevindik (2015), individuals with a bachelor's degree were happier than those with a master's degree. In the study, Korkut (2019) found that the group which declared they were the happiest group comprised teachers with associate degrees and the group with the lowest perception of organizational happiness consisted of teachers who had a master's degree. As the educational level increases, a relative decrease is observed in the perception of organizational happiness.

No significant difference could be detected in teachers' perceptions of organizational happiness according to the age variable. In their studies, Akyol (2016), Aydemir (2008), Birdoğan-Kuvvet (2019), Çolak (2018), Demirel (2018), Duran (2016), Öztaş (2018), Sevindik (2015), Şahin (2011), and Topuz (2013) concluded that the level of happiness did not differ significantly according to the age groups. In this study, the fact that the age factor did not create any significant difference in happiness may have resulted from the inclusion of many internal and instantaneous factors in the concept of happiness. Individuals want to be happy in every period, independently of their age, and they make an effort for it. Whether female or male, no individuals avoid happiness because they are young or old. There are physical and mental needs to be fulfilled during every age period. It can be said that fulfilling these needs will make individuals happy, no matter what age period they are in. Among the studies conducted, some studies are not parallel with these results. In the study, Şentürk (2011) reported that the happiness levels of individuals aged "between 18-24" and "65 and 
above" were high. In their study, Eryllmaz and Ercan (2011) stated that the age factor created a difference in the happiness level. Individuals aged "between 14-17" and "between 26-45" are happier than individuals aged "between 19-25". In the study conducted, Gülcan (2014) found a significant relationship between age and happiness. The happiness scores of individuals aged "between 19-22" were determined to be higher compared to individuals aged "between 23-25".

There was a significant difference in teachers' perceptions of organizational happiness only in the management processes subdimension of the School Happiness Scale according to professional seniority. A significant difference was observed in favor of those with professional seniority of " $0-5$ years" between teachers with professional seniority of " $0-5$ years" and "6-10 years", in favor of those with professional seniority of " $0-5$ years" between teachers with professional seniority of " $0-5$ years" and " $11-15$ years", and in favor of those with professional seniority of "16 years and above" between teachers with professional seniority of "16 years and above" and "11-15 years". According to the management processes subdimension, this can be said to be significant for teachers in the first five years and being in the profession for "16 years and above", and they are happier in terms of this subdimension. Being a new teacher with low professional seniority and experiencing high-level excitement and the professional self-confidence of teachers with high seniority due to their experiences may have created a positive effect on their happiness. Çetin and Polat (2019) stated that the organizational happiness of secondary school teachers with professional seniority of " $1-10$ years" was higher than that of teachers with professional seniority of "11-20 years". In his study, Korkut (2019) expressed that the perception of organizational happiness of teachers with seniority of " $1-5$ years", who were in their early years, was lower than the perception of organizational happiness of groups with professional seniority of "6-10 years", "16-20 years", and " $21+$ years", which suggested that organizational happiness would be gained over time and required a long time depending on other psychological factors. In his study, Bulut (2015) revealed that the organizational happiness of new teachers who had worked for a year was higher than that of teachers working for more years. In the study conducted, Düzgün (2016) reported that the seniority years of teachers created a significant difference in their happiness. Teachers with professional seniority of " 20 years and above" constituted the happiest group with the highest seniority participating in the study. In their studies, Birdoğan-Kuvvet (2019) and Özdemir and Kış (2019) stated that professional seniority did not affect happiness.

No significant difference could be detected in teachers' perceptions of organizational happiness according to the seniority in the school variable. In their studies, Bulut (2015), Çetin and Polat (2019), Duran (2016) and Düzgün (2016) indicated no difference between individuals' levels of happiness in terms of the seniority in the school factor.

When the teachers' perceptions of organizational happiness were examined, it was observed that teachers in verbal branches and primary school teachers were happier. Teachers in verbal branches and primary school teachers can express themselves in a better way, and this may affect their happiness. In the study conducted by Bulut (2015), it was concluded that teachers in verbal branches were happier than teachers in mathematics-science branches. As a result of the study carried out by Tingaz and Hazar (2014), the happiness scores of preservice physical education teachers and preservice primary school mathematics teachers were compared, and a significant difference was found between them. The happiness scores of preservice physical education and sports teachers were found to be higher than those of preservice primary school mathematics teachers. Özdemir and Kış (2019) stated that branch teachers received higher happiness scores than primary school teachers and explained this situation by the fact that it was tiring for primary school teachers to work with a young age group. Furthermore, they also mentioned the presence of positive feelings caused by branch teachers' allocating more time to themselves in the academic sense and professional satisfaction. In their studies, Duran (2016) and Uğur (2019) reported no significant difference between individuals' levels of happiness in terms of the branch variable.

Teachers' perceptions of organizational happiness differed significantly according to the level of education taught in the subdimensions of management processes and economic provision of the School Happiness Scale. In the economic provision subdimension, this significant difference was in favor of primary school teachers working in primary schools between teachers working in primary schools and teachers working in secondary schools, and in favor of primary school teachers working in primary schools between teachers working in primary schools and teachers working in high schools. In the management processes subdimension, this significant difference was in favor of branch teachers working in secondary schools between teachers working in primary schools and teachers working in secondary schools, and in favor of 
branch teachers working in high schools between teachers working in primary schools and teachers working in high schools. In his study, Bulut (2015) reported that teachers working in science high schools were happier than teachers working in vocational high schools. Moçoşoğlu and Kaya (2018) concluded in their study that the organizational happiness scores of teachers working in primary school were higher than those of teachers working in secondary school, which was shown to result from the long time spent with the same students by primary school teachers, and thus, the creation of a warmer atmosphere. Furthermore, as is stated, the fact that primary school teachers had their own classrooms might have affected their happiness by leading to a more intense sense of belonging and owning. Bekil (2019) and Uğur (2019), on the other hand, expressed that the type of the school where teachers worked did not have any impact on happiness.

Based on these results, the following recommendations can be made:

This study was conducted to determine teachers' levels of organizational happiness perception. It could not adequately reveal what situations organizational happiness is experienced in and what the expectations related to the organization are. For this reason, studies can be carried out by interviewing teachers, in a mixed design, including their answers to these questions and allowing for a more extensive and detailed description of the current situation. Researchers can investigate the relationship between leadership styles and organizational happiness.

\section{Acknowledgment}

This article was previously presented as a paper in 3rd International Social, Human and Educational Sciences Congress, on 17-18 December 2018, in Istanbul, Turkey.

\section{References}

Akduman, G., \& Yüksekbilgili, Z. (2015). Insan kaynaklarında yeni bir vizyon mutluluk yönetimi. Türkmen Kitapevi.

Akın, H. B., \& Şentürk, E. (2012). Bireylerin mutluluk düzeylerinin ordinal lojistik regresyon analizi ile incelenmesi. Öneri, 10(37), 183-193. https://dergipark.org.tr/tr/pub/maruoneri/issue/17895/187695

Akyol, Y. E. (2016). Akademisyenlerde mutluluğun yordayıclları olarak farkındalık ve stresle başa çıkma tutumları. Yayımlanmamış yüksek lisans tezi. Gazi Üniversitesi.

Arslan, Y. (2018). Öğretmenlerin farklllıkların yönetimi yaklaşımlarına ilişkin algıları ile örgütsel mutluluk algıları arasındaki ilişki. Yayımlanmamış doktora tezi. Kocaeli Üniversitesi.

Atay, B. (2012). Happiness in east europe in comparison with Turkey. Yayımlanmamış yüksek lisans tezi. İstanbul Bilgi Üniversitesi.

Aydemir, R. E. (2008). Dindarlık ve mutluluk ilişsisi (İlk yetişkinlik dönemi). Yayımlanmamış yüksek lisans tezi. Ondokuz Mayıs Üniversitesi.

Bekil, M. (2019). Öğretmenlerde mutluluğun yordaylcıları olarak sosyal bă̆lllık, özgecilik ve sosyal empati. Yayımlanmamış yüksek lisans tezi. Muğla Sıtkı Koçman Üniversitesi.

Birdoğan-Kuvvet, A. (2019). Okul müdürlerinin öğretim liderlikleri ile sinıf ögrretmenlerinin örgütsel mutlulukları arasındaki ilişki. Yayımlanmamış yüksek lisans tezi. Gazi Üniversitesi.

Bryson, A., Forth, J., \& Stokes, L. (2015). Does worker wellbeing affect workplace performance (pp. 1-37). Retrieved from https://ideas.repec.org/p/iza/izadps/dp9096.html

Bulut, A. (2015). Ortä̈ğretim öğretmenlerinin örgütsel mutluluk algllarının incelenmesi: bir norm çalışması. Yayımlanmamış doktora tezi. Gaziantep Üniversitesi.

Büyüköztürk, Ş., Kılıç-Çakmak, E., Akgün, Ö. E., Karadeniz, Ş., \& Demirel, F. (2012). Bilimsel araşttrma yöntemleri. Pegem Akademi.

Çetin, S. (2019). Ortaokul ögretmenlerinin örgütsel adalet algı düzeyleri ile örgütsel mutluluk düzeyleri arasındaki ilişki. Yayımlanmamış yüksek lisans tezi. Kocaeli üniversitesi.

Çetin, S., \& Polat, S. (2019). Ortaokul öğretmenlerinin örgütsel mutluluk algllarının analizi (p. 14). Uluslararas1 Eğitim Yönetimi Kongresi Tam Metin Bildiri Kitabı, Ankara.

Çirkin, Z., \& Göksel, T. (2016). Mutluluk ve gelir. Ankara Üniversitesi SBF Dergisi, 71(2), 375-400. https://doi.org/10.1501/SBFder_0000002397

Çolak, E. (2018). Sosyal Fayda Projelerinde Gönüllü Çalışan Üniversite Öğrencilerinde Mutluluk ve Psikolojik Yardım Aramaya Gönüllüllük Düzeylerinin Değerlendirilmesi. Yayımlanmamış yüksek lisans tezi. Beykent 
Üniversitesi.

Demir, R. (2017). Öğretmen adaylarının mutluluk, iyimserlik, yaşam anlamı ve yaşam doyumlarının incelenmesi. Yayımlanmamış yüksek lisans tezi. Gaziantep Üniversitesi. https://doi.org/10.26466/opus.347656

Demir, R., \& Murat, M. (2017). Öğretmen adaylarının mutluluk, iyimserlik, yaşam anlamı ve yaşam doyumlarının incelenmesi. Uluslararası Toplum Araştırmaları Dergisi, $7(7), \quad 3$. https://doi.org/10.26466/opus.347656

Demircan, T. (2019). Öğretmenlerin örgütsel bağlllık düzeyleri ile örgütsel mutlulukları arasındaki ilişkinin incelenmesi. Yayımlanmamış yüksek lisans tezi. Uşak Üniversitesi.

Demirel, C. (2018). Yetişkinlerde bağlanma stillerinin mutluluk yaşam doyumu ve depresyon ile ilişkisinin incelenmesi. Yayımlanmamış yüksek lisans tezi. Işık Üniversitesi.

Duman, S. (2014). Öğretmen adaylarında özgünlük ve öz-duyarlı̆̆ı mutluluk ile ilişkisinin incelenmesi. Yayımlanmamış yüksek lisans tezi. Karadeniz Teknik Üniversitesi.

Duran, A. (2016). Okul yöneticilerinin mutluluk düzeylerinin öz yeterlilikleriyle ilişsisi. Yayımlanmamış yüksek lisans tezi. Gaziosmanpaşa Üniversitesi.

Düzgün, O. (2016). Ortaokulda görev yapmakta olan öğretmenlerin mutluluk düzeyleri ile sinıf yönetimi becerileri arasındaki ilişki. Yayımlanmamış yüksek lisans tezi. Gaziosmanpaşa Üniversitesi.

Eckhaus E. (2018) Measurement of organizational happiness. In J. Kantola, T. Barath \& S. Nazir (Eds.), Advances in Human Factors, Business Management and Leadership (AHFE 2017, Advances in Intelligent Systems and Computing, vol. 594). Springer, Cham

Ekman, P., \& Friesen, W. V. (2003). Unmasking the face. Malor Books.

Erdoğan, H. (2017). Ortaokul yöneticilerinin öğretim liderlĭgi ile öğretmenlerin iş doyumu arasındaki ilişkinin incelenmesi. Yayımlanmamış yüksek lisans tezi. Sabahattin Zaim Üniversitesi.

Eryılmaz, A., \& Ercan, L. (2011). Öznel iyi oluşun cinsiyet, yaş grupları ve kişilik özellikleri açısından incelenmesi. Türk Psikolojik Danışma ve Rehberlik Dergisi, 4(36), 139-151. https://dergipark.org.tr/tr/pub/tpdrd/issue/21456/229650

Fisher, C. D. (2010). Hapiness at work. International Journal of Management Reviews, 12(4), 384-412. https://doi.org/10.1111/j.1468-2370.2009.00270.x

Franklin, S. S. (2010). The Psychology of Happiness. Cambridge University Press.

Gavin, J. H., \& Mason, R. O. (2004). The virtuous organization: The value of happiness in the workplace. Organizational Dynamics, 33(4), 379-392. https://doi.org/10.1016/j.orgdyn.2004.09.005

Göral, Ş. (2013). İnternet ortamında geçirilen boş zamanın üniversite öğrencilerinin mutluluk ve yaşam doyum değerlerine etkisi. Yayımlanmamış yüksek lisans tezi. Gazi Üniversitesi.

Gülcan, A. (2014). Genç yetişkinlerde iyimserliğin mutluluk ve yaşam doyumu üzerindeki etkisinin incelenmesi. Yayımlanmamış yüksek lisans tezi. Fatih Üniversitesi.

Hills, P., \& Argyle, M. (2002). The oxford happiness questionnaire: Acompact scale for the measurement of psychological well-being. Personality and Individual Differences, 33(7), 1073-1082. https://doi.org/10.1016/S0191-8869(01)00213-6

Huang, H. (2016). Workplace happiness: organizational role and the reliability of self-reporting. Unpublished Master's thesis. University of Maryland. Retrieved from https://drum.lib.umd.edu/bitstream/handle/1903/18191/Huang_umd_0117N_16920.pdf?sequence=1

Juul, L. K. (2018). Organizational happiness. Clearsight Publishing.

Kabal, D. (2019). Öğretmenlerin yaşam boyu öğrenme eğilimleri ve mutluluk düzeyleri üzerine bir çalışma (Kocaeli örneği). Yayımlanmamış yüksek lisans tezi. Sakarya Üniversitesi.

Kangal, A. (2013). Mutluluk üzerine kavramsal bir değerlendirme ve Türk hane halkı için bazı sonuçlar. Elektronik Sosyal Bilimler Dergisi, 12(44), 214-233.

Korkut, A. (2019). Öğretmenlerin örgütsel mutluluk, örgütsel sinizm ve örgütsel adalet algllarının analizi. Yayımlanmamış doktora tezi. İnönü Üniversitesi.

Kurnaz, M. (2015). İlk yetişkinlerde dini yönelim-mutluluk ilişsisi. Yayımlanmamış yüksek lisans tezi. Süleyman Demirel Üniversitesi. 
Moçoşoğlu, B., \& Kaya, A. (2018). Okul yöneticileri ve öğretmenlerin örgütsel sessizlik ile örgütsel mutluluk düzeyleri arasındaki ilişki: Şanlıurfa ili örneği. Harran Education Journal, 3(1), 52-70. https://doi.org/10.22596/2018.0301.52.70

Omar, M. K., Ramdani, N. F. S. M., Mohd, I. H., \& Hussein, N. (2018). Organizational happiness index (OHI): A study of a public university in Malaysia. International Journal of Academic Research in Business and Social Sciences, 8(11), 1984-1994. https://doi.org/10.6007/IJARBSS/v8-i11/5562

Ögüt, N. (2018). Kültürlerarası duyarlllık düzeyi ile etkin merkezcilik, yaşam doyumu ve mutluluk düzeyleri arasındaki ilişkinin incelenmesi. Yayımlanmamış doktora tezi. Selçuk Üniversitesi.

Özdemir, D. M., \& Kış, A. (2019). Öğretmenlerin mutluluk düzeylerinin incelenmesi: Gaziantep İli örneği. 14. Uluslararası Eğitim Yönetimi Kongresi Tam Metin Bildiri Kitabı, 2-4 Mayıs 2019, Ankara. Retrieved from https://www.pegem.net/dosyalar/dokuman/ICES-UEBK-TamMetin.pdf

Özgen, M. K. (2005). Farabî’nin mutluluk anlayıı̧ı. Yayımlanmamış doktora tezi. Erciyes Üniversitesi.

Özgenel, M., \& Bozkurt, B. (2020). Okul mutluluğunu yordayan bir faktör: Öğretmenlerin politik becerileri. Turkish Journal of Educational Studies, 7(2), 130-149. https://doi.org/10.33907/turkjes.701230

Öztaş, İ. (2018). Farklı kurumlarda çalışan memurların serbest zaman doyum ve mutluluk düzeylerinin belirlenmesi (Kırıkkale ili örneği). Yayımlanmamış yüksek lisans tezi. Ağrı İbrahim Çeçen Üniversitesi.

Öztürk, A. (2015). Öğretmenlerin sahip olduklari yaşam amaçlari ve sosyal desteğin öznel iyi oluş üzerindeki yordayıc1 rolü. Uluslararası Türk Eğitim Bilimleri Dergisi, 338-347. Retrieved from https://dergipark.org.tr/tr/pub/goputeb/issue/34517/385026

Pryce-Jones, J. (2011). Happiness at work. Maximizing Your Psychological Capital for Success. John Wiley and Sons.

Sancak, T. (2019). Öğretmenlerin okullardaki mekân düzenlemelerine ilişkin memnuniyetleri ile mutlulukları ve örgütsel băğlllkları arasındaki ilişki. Yayımlanmamış yüksek lisans tezi. İstanbul Sabahattin Zaim Üniversitesi.

Saygın, Y. (2008). Üniversite ögrencilerinin sosyal destek, benlik saygısl ve öznel iyi oluş düzeylerinin incelenmesi. Yayımlanmamış yüksek lisans tezi. Selçuk Üniversitesi.

Selim, S. (2008). Türkiye'de Bireysel mutluluk kaynağı olan değerler üzerine bir analiz: multinomial logit model. Ç.Ü. Sosyal Bilimler Enstitüsü Dergisi, 17, 345-358. http://dergipark.gov.tr/download/article-file/50493

Serter, K. (2019). Yerel yönetimler ve gençlik hizmetleri spor müdürlüğ̈̈nde görev yapan spor yöneticilerinin duygusal zekâ düzeyleri ile mutlulukları arasındaki ilişkinin incelenmesi. Yayımlanmamış yüksek lisans tezi. Marmara Üniversitesi. https://doi.org/10.35333/ERISS.2019.91

Sevindik, D. (2015). Orta yaş bireylerde dindarlık-mutluluk ilişkisi: Denizli örneği. Yayımlanmamış yüksek lisans tezi. Süleyman Demirel Üniversitesi.

Sönmez, M. (2016). İletişim ve mutluluk ilişsisi. Yayımlanmamış yüksek lisans tezi. Marmara Üniversitesi.

Stoia, E. (2015). Happiness and well-being at work. Literature Review. Retrieved from http://repositori.uji.es/xmlui/bitstream/handle/10234/161807/TFG_2015_StoiaE.pdf?sequence=1

Şahin, G. N. (2011). Üniversite ögrencilerinin kendini açma, öznel iyi oluş ve algıladıkları sosyal destek düzeylerinin karşılaş̧tırlması. Yayımlanmamış yüksek lisans tezi. Dokuz Eylül Üniversitesi.

Şahin, Y. (2015). Üniversite öğrencilerinin mutluluk, iyimserlik ve özgecilik düzeylerinin incelenmesi. Yayımlanmamış yüksek lisans tezi. Gaziosmanpaşa Üniversitesi.

Şaşmaz, Ş. C. (2016). Çocuğu olan evli ve evli olmayan bireylerin psikolojik sağlamlık ve mutluluk düzeylerinin incelenmesi. Yayımlanmamış yüksek lisans tezi. Beykent Üniversitesi.

Şengül, M., \& Demirel, A. (2016). Türkçe öğretmenlerinin duygu dışavurum tarzları üzerine bir inceleme. Mustafa Kemal Üniversitesi Sosyal Bilimler Enstitüsü Dergisi, 13(34), 116-133. https://dergipark.org.tr/tr/download/article-file/22644

Şentürk, E. (2011). Mutluluk düzeyinin sosyo-demografik özelliklerle lojistik regresyon analizi aractlı̆̆yla incelenmesi ve Türkiye için bir uygulama. Yayımlanmamış yüksek lisans tezi. Marmara Üniversitesi.

TDK, Türk Dil Kurumu. (2020, February 3). Büyük Türkçe sözlük: Güncel Türkçe sözlük. Retrieved from http://www.tdk.gov.tr/index.php?option=com_gts\&view=gts 
Tingaz, E. O. (2013). Beden ĕgitimi ve spor ögretmenliği ile bazı öğretmen adaylarının duygusal zekâ ve mutluluklarının karşılaştırılması. Yayımlanmamış yüksek lisans tezi. Gazi Üniversitesi.

Tingaz, E. O., \& Hazar, M. (2014). Beden eğitimi ve spor öğretmenliği ile bazı öğretmen adaylarının duygusal zekâ ve mutluluklarının karşılaşıtıılması. International Journal of Science Culture and Sport, 2(1), 745-756. https://doi.org/10.14486/IJSCS144

Topuz, C. (2013). Üniversite ögrencilerinde özgeciliğin öznel iyi oluş ve psikolojik iyi oluş ile ilişkisinin incelenmesi. Yayımlanmamış yüksek lisans tezi. Fatih Üniversitesi.

Turan, N. (2018). Çalışma mutluluğu: Kavram ve kapsam. Uludağ Journal of Economy and Society/B.U.Ü. İktisadi ve İdari Bilimler Fakültesi Dergisi, 37(1), 169-212. Retrieved from https://www.academia.edu/38544545/\%C3\%87al\%C4\%B1\%C5\%9Fma_Mutlulu\%C4\%9Fu_Kavram_ve_ Kapsam

Türkben, Y. (2010). Descartes' in ahlak ve mutluluk anlayışı. Hikmet Yurdu, 3(5), 239-250.

Uğur, S. (2019). Öğrenen okul ile okul mutluluğu arasındaki ilişki. Yayımlanmamış yüksek lisans tezi. Van Yüzüncü Y1l Üniversitesi.

Veenhoven, R. (2008). Healthy happiness: Effects of happiness on physical health and the consequences for preventive health care. Journal of Happiness Studies, 9(3), 449-469. https://doi.org/10.1007/s10902-006-9042-1

Yazıcı Ö. F. (2015). Beden eğitimi öğretmeni adaylarının mutluluk ve zindelik düzeylerinin incelenmesi. Yayımlanmamış yüksek lisans tezi. Karadeniz Teknik Üniversitesi.

Yıldız-Akyol, E. (2016). Akademisyenlerde mutluluğun yordayıcıları olarak farkındalık ve stresle başa çıkma tutumları. Yayımlanmamış yüksek lisans tezi. Gazi Üniversitesi.

Y1lmaz, Ö. (2019). Farkl okul türlerinde görev yapan ögrretmenlerin spiritüel iyi oluş düzeyleri ile mutluluk düzeyleri arasındaki ilişkinin incelenmesi. Yayımlanmamış yüksek lisans tezi. İstanbul Sabahattin Zaim Üniversitesi.

Yüksekbilgili, Z., \& Akduman, G. (2016). Bireysel mutluluk ve işkoliklik ilişkisi. Kocaeli Üniversitesi Sosyal Bilimler Dergisi, 31, 95-112. https://dergipark.org.tr/tr/pub/kosbed/issue/25688/271103

\section{Copyrights}

Copyright for this article is retained by the author, with first publication rights granted to the journal.

This is an open-access article distributed under the terms and conditions of the Creative Commons Attribution license (http://creativecommons.org/licenses/by/4.0/). 